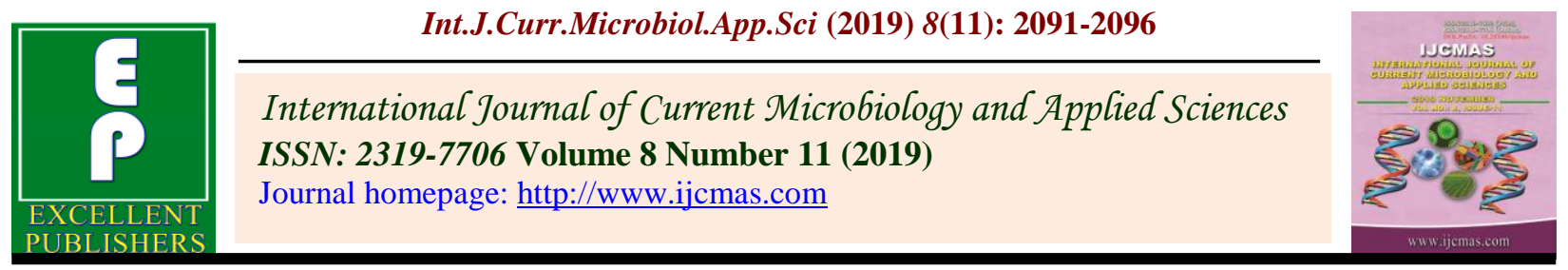

Original Research Article

https://doi.org/10.20546/ijcmas.2019.811.242

\title{
Inheritance Pattern of $\mathrm{F}_{2}$ Population of Melon (Cucumis Melo. L) for Various Fruit Traits and Ovary Characters
}

\author{
K.R. Kavya* and Shivapriya Manchali \\ Department of Biotechnology and Crop Improvement, College of Horticulture, Bengaluru, \\ University of Horticultural Sciences, Bagalkot-560 065, India \\ *Corresponding author
}

Keywords

Muskmelon, Chi square test, Segregation, Inheritance

\section{Article Info}

Accepted:

17 October 2019

Available Online:

10 November 2019

\section{A B S T R A C T}

\section{Introduction}

Melon (Cucumis melo L., $2 \mathrm{n}=2 \mathrm{x}=24$ ) of Cucurbitaceae family has great importance because of its commercial value and is grown mostly for its fruits. The center of origin of melon was believed to be East Africa, but the recent literature suggests the Asiatic origin (Schaefer et al., 2009 and Sebastian et al., 2010). C. melo is more diverse and polymorphic than other species in the genus (Pitrat et al., 2000) and such polymorphism is highest with respect to the fruit related traits such as shape, size, colour, texture, taste and composition. Melons play a significant role in supplying fresh fruits and vegetables used for salad, cooking, and dessert and it can also be candied. They contain high amount of water, rich in antioxidants, primary metabolites (protein, lipid and carbohydrate), several vitamins (Vitamin A, Vitamin B1, Vitamin B2, Vitamin B6, etc.) and minerals like potassium, calcium, iron, magnesium and phosphorous. The fruits have approximately 45 kcal energy per $100 \mathrm{~g}$ (Salunkhe and Kadam, 1998). Melon plants also contain various bioactive principles including elaterin, stigmasterol, spinosterol and the antitumour 
principle cucurbitacin. Duke and Ayensu (1985). Genetic variability in the genome is a pre requisite for crop improvement. The utilization of available genetic material in further breeding programme depends on the knowledge on extent of variability. The early segregating generations like $\mathrm{F}_{2} \mathrm{~S}$ provide wide variability for different traits and the inheritance pattern of characters could also be understood. $\mathrm{F}_{2} \mathrm{~s}$ also serve as mapping population to map genes and quantitative trait loci (QTL). In this context the present investigation was undertaken to study inheritance pattern using $\mathrm{F}_{2}$ population.

\section{Materials and Methods}

The study consists of parents, Kashi Madhu and COHB38, $F_{1}$ and $151 \quad F_{2}$ lines. The experiment was conducted in summer 2016 at College of Horticulture, Bengaluru. The $\mathrm{F}_{2} \mathrm{~S}$ were un-replicated and parents and $F_{1}$ were replicated four times. The experiment was conducted in green house condition with spacing of $2 \mathrm{~m} \times 0.45 \mathrm{~m}$. Observations were recorded on all $\mathrm{F}_{2} \mathrm{~s}$ of Kashi Madhu $\mathrm{X}$ COHB38, $F_{1}$ and parents. Morphological characterization of melon $\mathrm{F}_{2} \mathrm{~S}$ was done as per PPV \& FRA DUS guidelines. A chi square analysis was done to study the inheritance pattern of ovary and fruit traits for the data collected in this study. Characters of parents and $\mathrm{F} 1$ given in the table 1 for particular ovary characters and fruit traits.

\section{Results and Discussion}

According to data given in table 2, Inheritance of ovary pubescence in melon $\mathrm{F}_{2} \mathrm{~S}$ observed three classes, 40 lines with presence of pubescence (dense), sparse pubescence in 101 lines and pubescence was absent in 10 lines. The chi square calculated $\left(\chi^{2}=0.019 ; \mathrm{P}=\right.$ 0.990) discrepant with Mendelian 3: 1 ratio and fits into 9:6:1 ration indicated digenic control. Shape of the ovary in melons was observed as elongated (104) and round (47).
The segregation pattern $\left(\chi^{2}=0.082 ; \mathrm{P}=0.740\right)$ was in accordance with hypothetical 3:1 ratio clearly indicated that the ovary shape is controlled by single dominant gene. Fruit shapes in melon were found to be oblate (42 lines), ovate (36 lines) and intermediates (73 lines) in $F_{2}$ population of melon. The calculated chi square value $\left(\chi^{2}=0.725 ; \mathrm{P}=\right.$ 0.912 ) was deviated from $3: 1$ ratio and fitted into 1:2:1 indicated the nature of incomplete dominant gene action in the segregation pattern of fruit shape. Evaluation of fruit shape at peduncle end observed three classes such as truncate (21 lines), pointed (78 lines) and round (52 lines) in the present study. Test of goodness of fit revealed that the calculated chi square value was 0.002 with a probability of 0.990 and the ratio is deviated from hypothetical 3:1 ratio and showed a significant fit with expected 9:6:1 ratio, indicated that more than one gene control the inheritance. Inheritance pattern of fruit grooves in melon $\mathrm{F}_{2} \mathrm{~S}$ observed two classes, grooves were present in 139 lines and absent in 12 lines. The chi square calculated $\left(\chi^{2}=0.389 ; \mathrm{P}=0.532\right)$ was discrepant with mendelian 3: 1 ratio and fitted into $15: 1$ ratio indicating the digenic control for this trait. Presence or absence of sutures was observed on fruits of individual $\mathrm{F}_{2}$ plants. Out of 151 Plants, 135 plants were having sutures on fruits whereas sutureless fruits were found in 16 plants. It was tested against the expected Mendelian ratio of 3:1 using test for goodness of fit. The calculated chi square value $(0.012)$ with probability of 0.920 was in agreement with 13:3 revealed the digenic control on fruit suture. Among 151 Plants, fruit surface netting was present in 83 plants and absent in 68 plants. The chi square calculated $\left(\chi^{2}=0.748 ; \quad \mathrm{P}=0.387\right)$ was discrepant with mendelian 3:1 ratio and fitted into 9:7 ratio indicating the digenic control for this trait. Flesh firmness of fruit segregated into two classes such as crisp (39 lines) and soft (112 lines). The calculated chi square value $\left(\chi^{2}=0.814 ; \mathrm{P}=0.366\right)$ was fitted 
significantly in accordance with mendelian 3 : 1 indicated that the inheritance of flesh firmness is controlled by monogenic dominance. Fruit taste was observed in two classes, sweet (24 lines) and less sweet (127 lines) in the present study. Test of goodness of fit was done to know the segregation pattern in $\mathrm{F}_{2}$ population. It revealed that the calculated chi square value was 0.012 with a probability of 0.912 and showed a significant fit with expected 3:1 ratio that indicated the monogenic dominance for this trait.

The ovary pubescence was polymorphic in $\mathrm{F}_{2} \mathrm{~S}$ i.e. absent and present (sparse and dense). The Presence of ovary pubescence was noticed earlier by, Kirkbride (1993), Stepansky et al., (1999) and Sudhakara (2014) in melons. The variation in ovary characters is due to the genetic nature of plants under the influence of environmental factors. Based on visual observations, ovary shape was categorised into elongated and round ovary. Elongated ovary (85 $\mathrm{F}_{2}, \mathrm{COHB} 38$ and $\mathrm{F}_{1}$ ), medium elongated ovary $\left(19 \mathrm{~F}_{2}\right)$, medium round ovary $\left(2 \mathrm{~F}_{2}\right)$ and round shaped ovary (45 $\mathrm{F}_{2} \mathrm{~S}$ and Kashi Madhu). This is in confirmation with the studies conducted by Stepansky et al., (1999) in melons. Ovary shape is controlled by single dominant gene where, elongated ovary is dominant over round but Perin et al., (2002) reported six QTLs for ovary shape. A wide variation was found in $\mathrm{F}_{2} \mathrm{~s}$ for shape of fruit at peduncle and blossom end. Similar observations were made by Stepansky et al., (1999); Pitrat (2013) and Sudhakara (2014) in muskmelon in their studies. In the present study, some $\mathrm{F}_{2} \mathrm{~S}$ were found to have grooves on fruit surface and there was no grooves on other $\mathrm{F}_{2} \mathrm{~s}$. These observations were in collabration with Stepansky et al., (1999), Pitrat (2013) and Sudhakara (2014) in muskmelon. Inheritance pattern of fruit grooves in melon $\mathrm{F}_{2} \mathrm{~S}$ found to be controlled by more than one gene. This is in association with Takada et al., (1975) where he reported that ridge in fruit is recessive to ridge less.
Fruit suture was found on $135 \mathrm{~F}_{2} \mathrm{~S}$ including Kashi Madhu and $F_{1}$. Rest of the $F_{2} s$ and COHB38 were suture less. These observations were in accordance with Stepansky et al., (1999), Pitrat (2013) and Sudhakara (2014) in muskmelon. Inheritance of fruit suture found to be controlled by more than one gene. These were in collaboration with Perin et al., (1999) and Hagiwara and Kamimura (1936) where they reported sutureless is recessive to sutured nature. Fruit surface netting is one of the important traits for shelf life analysis in melons. Netted melons have less storage life, that may be a result of the presence of fissured epidermal tissue (netted), which is an elaborated system of lenticels as they are more prone to loose moisture and also the netted rind fruit melons produce higher amounts of ethylene at the stage of ripening (Pratt, 1971). In the present study, presence or absence of netting was studied including density of netting on fruits.

Variability in melon fruit surface netting was also observed in studies by Bokashi et al., (1992), Stepansky et al., (1999), Hossein et al., (2012), Pitrat (2013), Sudhakara (2014) and Mamatha (2016) in muskmelon. Flesh firmness and fruit flavour contribute for the overall quality of the fruit. The flesh firmness in $151 \mathrm{~F}_{2} \mathrm{~S}$ varied from firm to soft flesh. Similar results were recorded earlier by Khokhar et al., (1988) in muskmelon cultivars, Pitrat (2013) in wild and cultivated melons Sudhakara (2014) and Mamatha (2016) in muskmelon. The segregation of fruit flesh firmness in our study revealed that the inheritance of flesh firmness is controlled by monogenic dominant gene which is in collaboration with Chadha et al., (1972) and Ganeshan (1988), where they reported juicy flesh is dominant over crisp and mealy flesh is dominant over crisp texture. Fruit taste was sensory evaluated for its sweetness. Fruits of $24 \mathrm{~F}_{2}$ including Kashi Madhu were sweet in taste, 127 including COHB38 and $\mathrm{F}_{1}$ were less sweet and sour taste found in $27 \mathrm{~F}_{2}$. 
Table.1 A summary of ovary and fruit characters of parents and the hybrid

\begin{tabular}{|c|c|c|c|c|}
\hline $\begin{array}{r}\text { Sl. } \\
\text { No. }\end{array}$ & Characters & Kashi Madhu & COHB38 & $\begin{array}{c}\text { Kashi Madhu } \\
\times \mathbf{C O H B 3 8}\end{array}$ \\
\hline $\mathbf{1}$ & Ovary pubescence & Dense & Absent & Sparse \\
\hline $\mathbf{2}$ & Ovary shape & Round & Elongated & Elongated \\
\hline $\mathbf{3}$ & Fruit shape at longitudinal & Oblate & Ovate & Elongated globe \\
\hline $\mathbf{4}$ & Fruit shape in peduncle end & Truncate & pointed & Truncate \\
\hline $\mathbf{5}$ & Fruit grooves & Present & Absent & Absent \\
\hline $\mathbf{6}$ & Fruit sutures & Present & Absent & Present \\
\hline $\mathbf{7}$ & Fruit surface netting & Present & Absent & Absent \\
\hline $\mathbf{8}$ & Flesh firmness & Crisp & Soft & Soft \\
\hline $\mathbf{9}$ & Fruit taste & Sweet & Less sweet & Less sweet \\
\hline
\end{tabular}

Table. 2 Chi square analysis of 151 melon $\mathrm{F}_{2}$ lines of Kashi Madhu $\times$ COHB38 for ovary characters and fruit traits

\begin{tabular}{|c|c|c|c|c|c|c|c|c|}
\hline SI. No. & Characters & Categories & $\mathbf{O}$ & $\mathbf{E}$ & Ratio & $\chi^{2}$ & $\mathbf{P}$ & Gene action \\
\hline \multirow[t]{3}{*}{1} & \multirow{3}{*}{$\begin{array}{c}\text { Ovary } \\
\text { pubescence }\end{array}$} & Dense & 40 & 56.66 & \multirow[t]{3}{*}{ 9:6:1 } & \multirow[t]{3}{*}{0.019} & \multirow[t]{3}{*}{0.990} & \multirow[t]{3}{*}{ Digenic } \\
\hline & & Sparse & 101 & 84.94 & & & & \\
\hline & & Absent & 10 & 9.44 & & & & \\
\hline \multirow[t]{2}{*}{2} & \multirow[t]{2}{*}{ Ovary shape } & Elongated & 104 & 113.25 & \multirow[t]{2}{*}{$3: 1$} & \multirow[t]{2}{*}{0.082} & \multirow[t]{2}{*}{0.744} & \multirow{2}{*}{$\begin{array}{l}\text { Monogenic } \\
\text { complete } \\
\text { dominance }\end{array}$} \\
\hline & & Round & 47 & 37.75 & & & & \\
\hline \multirow[t]{3}{*}{3} & \multirow{3}{*}{$\begin{array}{l}\text { Fruit shape in } \\
\text { longitudinal } \\
\text { section }\end{array}$} & Oblate & 42 & 37.75 & \multirow[t]{3}{*}{$1: 2: 1$} & \multirow[t]{3}{*}{0.725} & \multirow[t]{3}{*}{0.912} & \multirow{3}{*}{$\begin{array}{l}\text { Monogenic, } \\
\text { Incomplete } \\
\text { dominance }\end{array}$} \\
\hline & & Intermediate & 73 & 75.50 & & & & \\
\hline & & Ovate & 36 & 37.75 & & & & \\
\hline \multirow[t]{3}{*}{4} & \multirow{3}{*}{$\begin{array}{l}\text { Fruit shape at } \\
\text { peduncle end }\end{array}$} & Truncate & 21 & 9.44 & \multirow[t]{3}{*}{ 9:6:1 } & \multirow[t]{3}{*}{0.002} & \multirow[t]{3}{*}{0.990} & \multirow[t]{3}{*}{ Digenic } \\
\hline & & Pointed & 78 & 84.94 & & & & \\
\hline & & Round & 52 & 56.66 & & & & \\
\hline \multirow[t]{2}{*}{5} & \multirow[t]{2}{*}{ Fruit groves } & Present & 139 & 141.56 & \multirow[t]{2}{*}{$15: 1$} & \multirow[t]{2}{*}{0.389} & \multirow[t]{2}{*}{0.532} & \multirow[t]{2}{*}{ Digenic } \\
\hline & & Absent & 12 & 9.44 & & & & \\
\hline \multirow[t]{2}{*}{6} & \multirow[t]{2}{*}{ Sutures } & Suture & 135 & 122.68 & \multirow[t]{2}{*}{$13: 3$} & \multirow[t]{2}{*}{0.012} & 0.920 & Digenic \\
\hline & & Sutureless & 16 & 28.32 & & & & \\
\hline 7 & Fruit surface & Present & 83 & 84.94 & $9: 7$ & 0.748 & 0.387 & Digenic \\
\hline & netting & Absent & 68 & 66.03 & & & & \\
\hline 8 & Flesh & Soft & 112 & 113.25 & $3: 1$ & 0.814 & 0.366 & Monogenic \\
\hline & firmness & Crisp & 39 & 37.75 & & & & $\begin{array}{l}\text { complete } \\
\text { dominance }\end{array}$ \\
\hline 9 & Fruit taste & Less sweet & 127 & 113.25 & $3: 1$ & 0.012 & 0.912 & Monogenic \\
\hline & & Sweet & 24 & 37.75 & & & & $\begin{array}{l}\text { complete } \\
\text { dominance }\end{array}$ \\
\hline
\end{tabular}


High value of total sugars is desirable because of consumer preferences but the sugar content varies depending upon the different fruit parts in melon (Chrost and Schmitz, 1996; Yativ et al., 2010) and also variation in sucrose levels accounts for the genetic differences in total sugar content and for the natural variability within a particular cultivar due to environmental differences (Stepansky et al., 1999). Inheritance of fruit taste was found to be monogenic dominant, less sweet fruits were dominant over sweet typed. This in in association with Kubicki (1962) where it was recorded sour is dominant over sweet fruit.

\section{References}

Bokashi, A. I., Mondal, S. N. and Monowar, H., 1992. Studies on the performance of muskmelon hybrids. Indian J. Hort., 49 (4): 354-357.

Chadha, M. L., Nandpuri, K. S. and Singh, S., 1972. Inheritance of some fruit characters in muskmelon. Indian. J. Hortic., 29: 58-62.

Chrost, B. and Schmitz, K., 1996. Changes in soluble sugar and activity of $\alpha$ galactosidases and acid invertase during muskmelon (Cucumis melo L.) fruit development. J. Plant Physiol., 151: 41-50.

Duke, J. A. and Ayensu, E. S., 1985. Medicinal plants of China. Ref. Publ., Inc., Michingan, 2:667-705.

Ganesan, J., 1988. Genetic studies on certain characters of economic importance in muskmelon (Cucumis melo L.). Annamalai Uni. (India).

Hagiwara, T. and Kamimura, K., 1936. Crossbreeding experiments in Cucumis melo. Tokyo Horticultural School Publication, pp.75-85.

Hossein, N. N., Hossein N., Alireza, S. and Mansoureh, S., 2012. Study on morphologic variation of different Iranian melon cultivars (Cucumis melo
L.). African J. Agri. Res., 7 (18): 27642769.

Khokhar, K. M., Zahur, A., Hussain, S. I. and Tariq, M., 1988. Comparative studies on the evaluation of some foreign and local muskmelon cultivars. J. Agric. Res., 9(4): 552-555.

Kirkbride, J. H., 1993. Biosystematic monograph of the genus Cucumis (Cucurbitaceae). Parkway publishers, Boone (NC, US).

Kubicki, B., 1962. Inheritance of some characters in muskmelons (Cucumis melo). Genetica Polonica, 3: 265-274.

Mamatha., 2016. Studies on genetic diversity using morphological characters and health beneficial components in muskmelon (cucumis melo L.). M.Sc. Thesis, Univ. Hortic. Sci., Bagalkot (India), pp. 1-117.

Perin, C., Hagen, L. S., Giovinazzo, N., Besombes, D., Dogimont, C. and Pitrat, M., 2002. Genetic control of fruit shape acts prior to anthesis in melon (Cucumis melo L.). Mol. Genet. Genomics, 266: 933-941.

Pitrat, M., 2013. Phenotypic diversity in wild and cultivated melons (Cucumis melo). Plant Biotech., 30: 273-278.

Pitrat, M., 2013. Phenotypic diversity in wild and cultivated melons (Cucumis melo). Plant Biotech., 30: 273-278.

Pratt, H., 1971. Melons: In biochemistry of fruits and their products, Hulme A (eds), Academic Press, London. pp. 207-232.

Salunkhe, D. K. and Kadam, S. S., 1998. Handbook of Vegetable Science and Technology: Production, Composition, Storage and Processing. CRC PressTechnology and Engineering, pp. 230245.

Schaefer, H., Heibl, C. and. Renner, S. S., 2009. Gourds afloat: a dated phylogeny reveals an Asian origin of the gourd family (Cucurbitaceae) and 
numerous oversea dispersal events. Proc. Royal Soc. Bot. 276: 843-851.

Sebastian, P., Schaefer, H., Telford, I. R. H. and Renner, S. S., 2010. Cucumber (Cucumis sativus) and melon (C. melo) have numerous wild relatives in Asia and Australia, and the sister species of melon is from Australia. Proc. Natl Acad. Sci. USA. 107: 14269-14273.

Stepansky, A., Kovalski, I. and Rafael, P. T., 1999. Intraspecific classification of melons (Cucumis melo L.) in view of their phenotypic and molecular variation. Plant Syst. Evol., 217: 313333.

Sudhakara, T., 2014. Characterization of muskmelon local types of Karnataka for morphological traits, nutritional qualities and resistance to downy mildew disease. M. Sc. Thesis, Univ. Hortic. Sci., Bagalkot (India), pp. 1-91.

Takada, K., Kanazawa, K., Takatuka, K. and Takatsu, K. A., 1975. Studies on breeding for resistant to powdery mildew in melon I varietal differences in resistance and the breeding of the variety sunrise. Bull. Veg. Orna. Crop Res. Station, 1: 59-91.

Yativ, M., Haray, I. and Wolf, S., 2010. Sucrose accumulation in watermelon fruits: Genetic variation and biochemical analysis. J. Plant Physiol., 167: 589-596.

\section{How to cite this article:}

Kavya, K.R. and Shivapriya Manchali. 2019. Inheritance Pattern of $F_{2}$ Population of Melon (Cucumis Melo. L) for Various Fruit Traits and Ovary Characters. Int.J.Curr.Microbiol.App.Sci. 8(11): 2091-2096. doi: https://doi.org/10.20546/ijcmas.2019.811.242 